\title{
DISTILASI AZEOTROP CAMPURAN ETANOL-AIR UNTUK MENINGKATKAN KADAR ETANOL MENGGUNAKAN ENTRAINER ETIL ASETAT
}

\author{
Retno Indarti ${ }^{1}{ }^{*}$, Rintis Manfaati ${ }^{1}$, Ari Marlina ${ }^{1}$, Keryanti $^{1}$ \\ ${ }^{1}$ Jurusan Teknik Kimia, Politeknik Negeri Bandung, Jl. Gegerkalong Hilir-Ds.Ciwaruga, Bandung 40012 \\ *E-mail: ret.indarti@gmail.com
}

\begin{abstract}
ABSTRAK
Bioetanol yang dapat digunakan sebagai campuran bahan bakar alternatif harus memiliki kadar etanol 99\%, sehingga perlu proses pemurnian terhadap campuran etanol yang masih mengandung air. Distilasi sederhana campuran etanol-air menggunakan bahan tambahan (entrainer) etil asetat dapat meningkatkan kadar etanol. Pada penelitian ini, pemurnian etanol dilakukan dengan proses distilasi azeotrop pada tekanan atmosfer dan suhu penangas air sebesar $70-75^{\circ} \mathrm{C}$. Komposisi umpan terdiri dari campuran etanol yang mengandung air dan etil asetat sebagai entrainer. Penelitian dilakukan sebanyak 5 partaian (batch) dengan variasi penambahan etil asetat ke dalam umpan sebanyak $10 \% \mathrm{v} / \mathrm{v}, 20 \% \mathrm{v} / \mathrm{v}, 30 \% \mathrm{v} / \mathrm{v}, 40 \% \mathrm{v} / \mathrm{v}$ dan $50 \% \mathrm{v} / \mathrm{v}$. Hasil penelitian menunjukkan kadar etanol tertinggi dengan waktu yang paling singkat ialah pada penambahan etil asetat sebagai entrainer sebesar 30\% v/v, yang terdiri dari campuran $15 \mathrm{ml}$ etil asetat dan 35 $\mathrm{ml}$ etanol $80 \%$. Hasil analisis dengan kromatografi gas memperoleh konsentrasi etanol sebesar 99.80\% dan waktu distilasi selama 90 menit.
\end{abstract}

Kata kunci: Etanol, etil asetat, distilasi azeotrop, entrainer

\begin{abstract}
ABTRACT
Bioethanol that can be used as an alternative fuel mixture must have an ethanol content of $99 \%$, so it is necessary to carry out a purification process for the ethanol mixture that still contains water. Simple distillation of the ethanol-water mixture using ethyl acetate entrainer carried out to increase the ethanol content. In this study, ethanol purification was carried out by azeotropic distillation process at atmospheric pressure and a water bath temperature of $70-75 \mathrm{oC}$. The feed composition consisted of a mixture of ethanol containing water and ethyl acetate as an entrainer. The study was conducted for 5 runs with variations in the addition of ethyl acetate into the feed as much as $10 \% \mathrm{v} / \mathrm{v}, 20 \% \mathrm{v} / \mathrm{v}, 30 \% \mathrm{v} / \mathrm{v}, 40 \% \mathrm{v} / \mathrm{v}$ and $50 \% \mathrm{v} / \mathrm{v}$. The results obtained are the addition of ethyl acetate to the feed which shows the highest ethanol content in the shortest time was the addition of ethyl acetate as an entrainer of $30 \% \mathrm{v} / \mathrm{v}$, which consists of a mixture of $15 \mathrm{ml}$ of ethyl acetate and $35 \mathrm{ml}$ of $80 \%$ ethanol. The results of the analysis carried out by gas chromatography obtained an ethanol concentration of $99.80 \%$ and a distillation time of 90 minutes.
\end{abstract}

Keywords: Ethanol, ethyl acetate, azeotropic distillation, entrainer

\section{PENDAHULUAN}

Seiring dengan pesatnya perkembangan zaman, membuat kebutuhan akan etanol sangat meningkat hingga perlu berbagai cara untuk mendapatkan etanol murni dengan konsentrasi yang tinggi. Hal ini disebabkan banyaknya penggunaan etanol terutama pada industri obat, industri kosmetik, industri makanan dan minuman, industri farmasi, industri kimia, dunia pendidikan, dan rumah sakit. Namun sumber daya alam yang kian hari kian menipis mendorong diperlukannya pengembangan sumber energi alternatif dari bahan-bahan alam yang jumlahnya melimpah dan bersifat terbarukan.

Bioetanol merupakan salah satu sumber energi alternatif karena dihasilkan dari bahan baku tumbuhan melalui proses fermentasi dan distilasi. Produksi bioetanol mencakup tiga tahapan proses, yaitu: persiapan bahan 
baku, fermentasi dan penyulingan atau pemurnian. Pemurnian etanol dapat dilakukan dengan cara penghilangan kandungan air dalam etanol. Penghilangan kandungan air dapat dilakukan dengan adsorbsi dan distilasi (Novitasari, 2014).

Salah satu kegunaan dari bioetanol adalah sebagai campuran bahan bakar motor bensin. Bioetanol yang ditambahkan dalam campuran bahan bakar diatur dalam Standar Nasional Indonesia (SNI) nomor 7390 tahun 2008 yaitu dengan kadar 99\%. Menurut Prasetyo (2009) dengan adanya campuran bioetanol dalam bahan bakar motor menyebabkan gas buang (emisi) berbahaya yang dihasilkan lebih rendah dan kinerja kendaraan semakin baik.

Konsentrasi 99\% etanol (pure analytic) dapat diperoleh dengan cara adsorbsi etanol menggunakan zeolit sebagai adsorbennya (Novitasari, 2007), juga dapat diperoleh dengan menambahkan zat tambahan (entrainer) yang berfungsi mengikat kandungan air dalam etanol kemudian dilakukan distilasi. Etanol yang dimurnikan dengan cara distilasi sederhana hanya dapat mencapai konsentrasi 96\%. Hal tersebut dikarenakan pada konsentrasi tersebut komposisi fraksi cair sama dengan komposisi fraksi uapnya (azeotropic condition). Pada kondisi azeotrop, etanol tidak dapat dimurnikan lagi. Oleh karena itu perlu metode lain untuk memisahkan campuran etanol air.

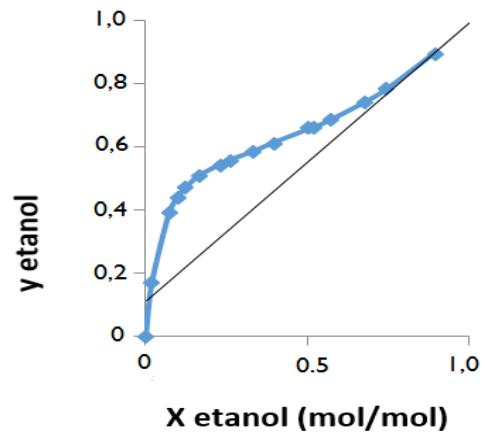

Gambar 1. Kurva Kesetimbangan Etanol Air

Berdasarkan Gambar 1 diketahui bahwa pemurnian campuran etanol dan air membentuk titik azeotrop pada komposisi $0,96 \mathrm{~mol} / \mathrm{mol}$. Terbentuknya titik azeotrop tersebut menyebabkan etanol tidak dapat dimurnikan lagi sehingga diperlukan adanya penambahan senyawa lain yang dapat menyerap molekul air yang tercampur dalam etanol tersebut. Senyawa yang ditambahkan ini disebut sebagai entrainer. Penambahan entrainer kedalam suatu distilasi berfungsi menurunkan titik azeotrop, sehingga proses distilasi seperti ini disebut distilasi azeotrop. Beberapa senyawa yang dapat digunakan sebagai bahan tambahan (entrainer) disajikan dalam Tabel 1.

Tabel 1. Macam-macam Entrainer dalam Kondisi Atmosferik

\begin{tabular}{lccrcc}
\hline \multirow{2}{*}{ Komponen } & \multicolumn{2}{c}{ Boiling Point } & \multicolumn{3}{c}{ Komposisi \%berat } \\
& Kompn. & Azeotrop & Air & Etanol & Kompn. \\
\hline Etil Asetat & 77,1 & 70,3 & 7,8 & 9,0 & 83,2 \\
Sikloheksan & 86,8 & 62,1 & 7 & 17,0 & 76 \\
Dietil Asetal & 103,6 & 77,8 & 11,4 & 27,6 & 61 \\
Etil Iodida & 72,3 & 61 & 5 & 9 & 86 \\
Klorida & 83,7 & 66,7 & 5 & 17 & 78 \\
Etilen & & & & & \\
\hline
\end{tabular}

Sumber : Walas (1988)

Penelitian ini menggunakan senyawa etil asetat sebagai entrainer. Berikut karakteristik senyawa entrainer:

1. Di dalam campuran harus mempunyai kenaikan nilai relativitas relatif $(\alpha)$ dari komponen utama,

2. Mempunyai panas laten yang rendah dibandingkan komponen lainnya (lihat Tabel 2)

3. Mempunyai kestabilan termal

4. Komponen yang tidak reaktif

5. Komponen yang tidak beracun

6. Komponen yang tidak korosif

7. Mudah dipisahkan dari campuran

8. Mudah larut dengan komponen lain dalam kolom distilasi.

Tabel 2. Panas Laten Etanol, Air dan Etil Asetat

\begin{tabular}{lc}
\hline Komponen & Panas Laten, J/mol \\
\hline Etanol & 38577,3 \\
Air & 40656,2 \\
Etil asetat & 32269,4 \\
\hline \multicolumn{2}{c}{ (Sumber : Schneider. 1983) }
\end{tabular}

Etil asetat dapat melarutkan air hingga 3\% dan larut dalam air hingga kelarutan 8\% pada suhu kamar. Kelarutannya meningkat 
pada suhu yang lebih tinggi. Distilasi campuran etanol-air dengan penambahan entrainer etil asetat akan menyebabkan titik azeotropnya turun menjadi $70,3^{\circ} \mathrm{C}$. Etil asetat akan mengikat air dan menguap pada temperatur $70,3^{\circ} \mathrm{C}$, sehingga distilat dari proses pemisahan terdiri dari etil asetat dan air, sedangkan etanol sebagai residu.

Gambar 2 menunjukkan kurva kesetimbangan antara campuran etanol-air dengan kesetimbangan etil asetat-etanol. Berdasarkan Gambar 2 dapat diketahui bahwa dengan adanya penambahan entrainer etil asetat, titik azeotrop etanol yang sebelum penambahan entrainer etil asetat sebesar 0,89 mol menjadi 0,54 mol.

Penelitian yang dilakukan oleh Jaelani (2007) menyatakan bahwa etanol hasil distilasi fraksionasi menggunakan sistem refluks dengan penambahan entrainer etil asetat pada kondisi temperatur proses $85^{\circ} \mathrm{C}$ dan umpan $3000 \mathrm{ml}$ yang terdiri dari $2880 \mathrm{ml}$ etanol kadar $96 \%$ dan $120 \mathrm{~mL}$ etil asetat kadar 99\% mampu menghasilkan etanol dengan kadar 99,997\%.

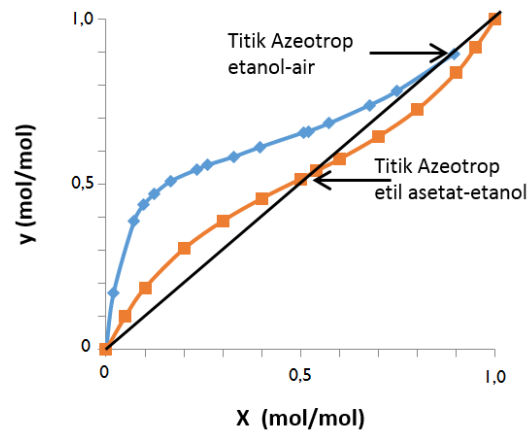

Gambar 2. Kurva Kesetimbangan Campuran Etanol-Air dan Campuran Etil Asetat-Etanol

Berdasarkan penelitian yang dilakukan oleh Jaelani tersebut, penelitian ini dilakukan bertujuan untuk meningkatkan konsentrasi etanol $80 \%$ menjadi etanol yang lebih murni dengan kadar $99 \%$ dengan menggunakan proses distilasi azeotrop. Analisis yang dilakukan meliputi analisis kadar bioetanol hasil distilasi dengan pengukuran indeks bias menggunakan alat refraktometer dan penentuan kadar/konsentrasi etanol menggunakan alat Gas Chromatografi (GC).

\section{METODE}

Penelitian ini terdiri dari beberapa tahapan yang berkesinambungan.

Tahap Persiapan, di antaranya merangkai alat-alat distilasi azeotrop dan menyiapkan bahan kimia yang digunakan yaitu etanol $80 \%$ dan etil asetat $99 \%$. Berikut ini gambar dari rangkaian alat distilasi azeotrop.

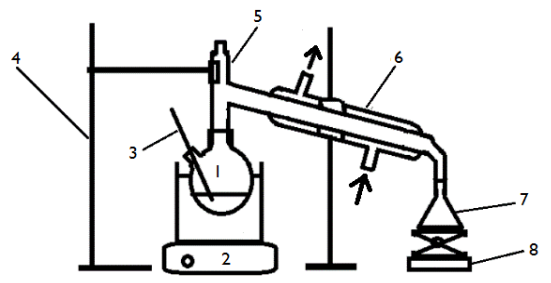

Gambar 3. Rangkaian Alat Distilasi Azeotrop

Keterangan:

1. Reaktor labu leher dua, $250 \mathrm{ml}$

2. Penangas Air (Waterbath)

3. Termometer

4. Statif dan klem

5. Claisen

6. Kondensor Liebig

7. Erlenmeyer (labu penampung distilat)

8. Pengungkit

Tahap Pelaksanaan, pada tahap ini dilakukan proses distilasi azeotrop menggunakan sistem batch dalam skala laboratorium. Proses distilasi azeotrop ini dilakukan dengan penambahan etil asetat sebagai entrainer. Umpan yang dimasukkan adalah campuran etanol, air dan etil asetat sampai volume campuran $50 \mathrm{~mL}$.

Parameter yang divariasikan adalah jumlah etil asetat yang ditambahkan, yaitu 5 $\mathrm{mL}, 10 \mathrm{~mL}, 15 \mathrm{~mL}, 20 \mathrm{~mL}$ dan $25 \mathrm{~mL}$, sehingga komposisi umpan untuk proses distilasi adalah sebagai berikut:

Tabel 3. Komposisi Campuran Etil asetat dan Etanol

\begin{tabular}{ccc}
\hline No. & $\begin{array}{c}\text { Etil Asetat } \\
\mathbf{9 9 \%}(\mathbf{m l})\end{array}$ & $\begin{array}{c}\text { Etanol } \\
\mathbf{8 0 \%}(\mathbf{m l})\end{array}$ \\
\hline 1. & 5 & 45 \\
2. & 10 & 40 \\
3. & 15 & 35 \\
4. & 20 & 30 \\
5. & 25 & 25 \\
\hline
\end{tabular}


Campuran etanol dan etil asetat kemudian didistilasi secara batch pada temperatur $75^{\circ} \mathrm{C}$ selama 90 menit, sebagai variabel tetap.

Tahap analisis. Produk yang dihasilkan dari proses distilasi adalah etanol yang terdapat dalam residu. Analisis awal produk etanol, ditentukan indeks biasnya dengan alat refraktometer. Selanjutnya ditentukan konsentrasi etanol dengan alat kromatografi gas.

HASIL DAN PEMBAHASAN

Hasil analisis indeks bias dan konsentrasi etanol produk hasil distilasi disajikan dalam Tabel 4.

Tabel 4. Hasil Analisis Indeks Bias konsentrasi Etanol Produk

\begin{tabular}{ccc}
\hline $\begin{array}{c}\text { Etil Asetat } \\
(\mathbf{m l})\end{array}$ & $\begin{array}{c}\text { Indeks } \\
\text { Bias (nD) }\end{array}$ & $\begin{array}{c}\text { Konsentrasi } \\
\text { etanol (\%) }\end{array}$ \\
\hline 5 & 1.36290 & 65,94 \\
10 & 1.36235 & 63,98 \\
15 & 1.36305 & 66,49 \\
20 & 1.36270 & 65,23 \\
25 & 1.36195 & 62,54 \\
\hline
\end{tabular}

Berdasarkan Tabel 4 di atas dapat diketahui konsentrasi etanol tertinggi yaitu $66,49 \%$ diperoleh pada umpan dengan penambahan etil asetat sebesar $15 \mathrm{~mL}$. Namun, penentuan konsentrasi etanol berdasarkan indeks bias belum mencapai konsentrasi lebih dari 90\%. Penentuan konsentrasi etanol dengan metode tidak langsung yaitu melalui angka indeks bias merupakan metode yang paling sederhana dan mudah dilakukan. Pada penelitian ini dapat ditunjukkan bahwa metode ini tidak cocok diterapkan pada larutan sistem etanolair-asam asetat, karena angka indeks bias etil asetat mempengaruhi angka indeks bias secara keseluruhan, sehingga perlu dilakukan analisis selanjutnya dengan menggunakan kromatografi gas. Perolehan konsentrasi etanol dalam residu disajikan dalam Tabel 5.

Berdasarkan Tabel 5, perolehan produk etanol terbanyak berada pada penambahan umpan etil asetat sebanyak $15 \mathrm{ml}$, dengan perolehan produk etanol sebanyak $27,2 \mathrm{ml}$ dengan konsentrasi etanol dalam residu sebesar 99,8\%. Hal ini menunjukan bahwa pada penambahan etil asetat sebesar $15 \mathrm{~mL}$ merupakan proses distilasi yang terbaik dalam penelitian ini.

Tabel 5. Perolehan Konsentrasi Etanol Hasil Distilasi Azeotrop

\begin{tabular}{cccc}
\hline $\begin{array}{c}\text { Etil Asetat } \\
(\mathbf{m l})\end{array}$ & $\begin{array}{c}\text { Konsentrasi } \\
\text { Etanol dalam } \\
\text { Residu (\%) }\end{array}$ & $\begin{array}{c}\text { Waktu } \\
\text { (menit) }\end{array}$ & $\begin{array}{c}\text { Vol.Etanol } \\
\text { Akhir (ml) }\end{array}$ \\
\hline 5 & 99,8 & 90 & 20 \\
10 & 99,8 & 90 & 15 \\
15 & 99,8 & 90 & 27,2 \\
20 & 99,8 & 90 & 6,1 \\
25 & 99.8 & 90 & 4,4 \\
\hline
\end{tabular}

Perolehan konsentrasi etanol dalam residu dan perolehan konsentrasi etil asetat dalam distilat disajikan dalam Gambar 4. Berdasarkan Gambar 4 diketahui bahwa secara keseluruhan konsentrasi etanol dalam residu sebesar 99,8\%. Volume etanol terbanyak yang dihasilkan yaitu $27,2 \mathrm{~mL}$ yang diperoleh pada penambahan etil asetat sebanyak $15 \mathrm{~mL}$.

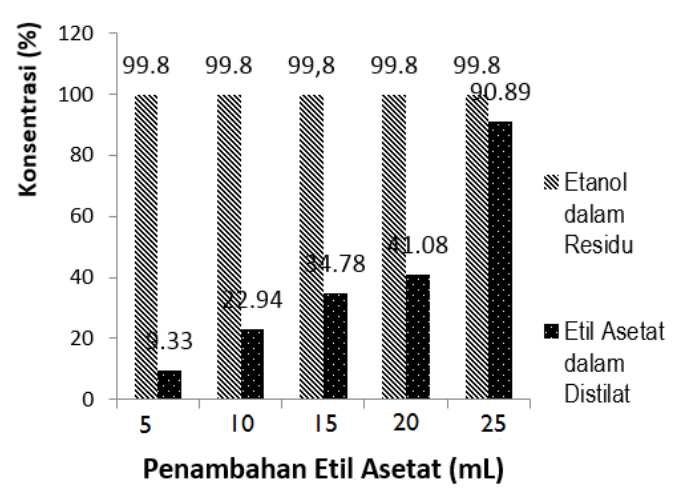

Gambar 4. Korelasi antara Penambahan Etil Asetat terhadap Konsentrasi Etanol dalam Residu

Tabel 5 dan Gambar 4 menunjukkan bahwa penambahan etil asetat sebagai entrainer berhasil memisahkan etanol hingga mencapai konsentrasi 99,8\%. Perbedaan yang signifikan dari variasi penambahan volume etil asetat adalah pada konsentrasi etil asetat yang diperoleh di distilat. Semakin tinggi volume etil asetat yang ditambahkan semakin tinggi pula konsentrasi etil asetat dalam destilat.Hal tersebut menunjukkan bahwa air-etil asetat 
dapat dipisahkan dari etanol secara signifikan.

Pada proses distilasi sistem air-etil asetat-etanol dengan volume umpan yang tetap yaitu $50 \mathrm{ml}$, penambahan volume entrainer etil asetat akan mempengaruhi volume etanol 99,8\% yang diperoleh dalam residu. Volume etanol 99,8 \% meningkat pada penambahan etil asetat $5 \mathrm{ml}$ sampai dengan $15 \mathrm{ml}$, namun menurun pada penambahan etil asetat $20 \mathrm{ml}$ sampai dengan $25 \mathrm{ml}$. Hal tersebut berkaitan erat dengan volatilitas sistem air-etil asetat. Semakin tinggi volume etil asetat yang ditambahkan maka sistem air-etil asetat semakin volatile atau semakin mudah menguap. Namun penambahan volume etil asetat yang berlebih menghasilkan kondisi jenuh sehingga didalam sistem tersebut terdapat etil asetat bebas yang tidak berikatan dengan air. Kondisi tersebut akan menghambat proses pemisahan etanol dari air-etil asetat.

Penelitian yang dilakukan oleh Jaelani (2007) diperoleh etanol dengan konsentrasi $99,997 \%$ pada sistem distilasi dengan refluks, dengan perbandingan volume entrainer terhadap volume umpan adalah 120/3000, sedangkan pada penelitian ini diperoleh etanol dengan konsentrasi 99,8\% pada perbandingan volume entrainer terhadap volume umpan adalah 15/50 tanpa refluks. Dapat dijelaskan bahwa tanpa penggunaan refluks dibutuhkan jumlah entrainer yang sangat besar untuk menghasilkan konsentrasi etanol yang sama.

\section{SIMPULAN}

Berdasarkan penelitian yang dilakukan dapat diambil kesimpulan bahwa kondisi operasi terbaik dalam proses distilasi azeotrop ini terletak pada penambahan entrainer etil asetat sebesar $15 \mathrm{~mL}$, pada suhu $75^{\circ} \mathrm{C}$ selama 90 menit. Konsentrasi etanol yang diperoleh $99,80 \%$ sebanyak 27,2 $\mathrm{mL}$.

\section{UCAPAN TERIMA KASIH}

Penulis mengucapkan terima kasih kepada Ais Aisyah dan Fidhiana serta tim peneliti yang telah membantu dalam penelitian ini.
DAFTAR RUJUKAN

Dean, John A. 1987. Lange's Handbook of Chemistry 13rd Edition. New York : McGraw-Hill Book Company

Jaelani, Rani. 2007. Pengaruh Perbandingan Refluks (Reflux Ratio) pada Distilasi Azeotrop untuk Pemisahan Etanol - Air - Etil Asetat. Bandung : Politeknik Negeri Bandung

Novitasari, dkk. 2007. Pemurnian Bioetanol Menggunakan Proses Adsorbsi dan Distilasi Adsorbsi dengan Adsorben Zeolit. Semarang : Universitas Diponegoro

Prasetyo, Devanta Bayu dan Fajar Patriayudha. 2009. Pemakaian Gasohol Sebagai Bahan Bakar Kendaraan Bermotor. Semarang : Universitas Diponegoro

Schneider, Daniel R. 1983. Introduction To Material and Energy Balances. USA: G.V Reklaitis

Standar Nasional Indonesia (SNI). Bioetanol Terdenaturasi untuk Gasohol SNI 7390:2008 (online)

Walas, Stainley. 1988. Chemical Process Equipment. USA : Butter Worth Publisher 